\title{
WAGE SLAVERY AND THE COMPOSITION OF LEAVES OF GRASS: THE “TALBOT WILSON" NOTEBOOK
}

\author{
ANDREw C. Higgins
}

OVER THE PAST TEN YEARS it has become a commonplace in Whitman studies to claim that the seeds of Leaves of Grass lie in Whitman's outrage over slavery, specifically over the Compromise of 1850 . The prime piece of evidence for this is a passage from an early notebook thought to be written around 1850, in which he declares (in what are taken to be the first mature lines of Whitman's poetry), "I am the poet of slaves and of the masters of slaves." ${ }^{1}$ However, with the rediscovery of the "Talbot Wilson" notebook, which had been missing for fifty years, we can see that, in the words of Alice L. Birney of the Library of Congress's Manuscript Division, "a more likely date for these drafts-with prose breaking into poetry -is 1853-1854."2 Far from being the earliest of Whitman's notebooks, this revised dating would make it one of the later pre-Leaves of Grass notebooks.

Because the voice of the Talbot Wilson notebook is so similar to that of Leaves of Grass, it has been difficult to talk about Whitman's development in the notebooks. More specifically, because Whitman's first mature lines in the "Talbot Wilson" notebook are about slavery, Whitman's comments on race and slavery in the other early notebooks have gone largely unexamined. The revised dating of the "Talbot Wilson" notebook requires us to revisit these passages, and a careful analysis of racial imagery in these notebooks reveals that Whitman first used images of blacks and slaves as a trope for ownership; that these earliest images of blacks and slaves are one-dimensional; that it is not until Whitman begins to play with these images that he recognizes the humanity of African American figures in his poetry. This use of slaves and blacks as a trope for ownership grows out of the poet's involvement in artisanal class movements and the wage slavery rhetoric common to that movement. Far from slavery driving Whitman to poetry, it was, as scholars such as Joseph Jay Rubin and M. Wynn Thomas have argued, his concern about class that propelled Whitman towards poetry in the mid-1850s, and it was his democratic poetics, developed in the later notebooks and grounded in the actions of the human body, that pushed Whitman to revise static caricatures of African Americans into robust 
individuals like the slave on the auction block in "I Sing the Body Electric," images that would later prompt Langston Hughes to describe Whitman as "the Lincoln of our letters."

Since Edward Grier's 1968 article "Walt Whitman's Earliest Known Notebook" identified it as such, there has been little debate over the dating of the "Talbot Wilson" notebook (Library of Congress \#80). 4 And with the great interest in Whitman's thoughts and political stand on slavery, the notebook has been seen as a major piece of evidence that the roots of Leaves of Grass are tied up with slavery. David S. Reynolds, in Walt Whitman's America, writes that, "since Whitman's earliest notebook jottings in his characteristic free verse were dated $1847 \ldots$ and pertained to slavery, it is essential to consider his attitude toward the institution." And in a footnote he is even more emphatic:

It should be emphasized that although Whitman had previously done a few jottings toward the 1855 Leaves of Grass, these lines about slavery were his first notebook lines arranged as poetry, underscoring my point that his "discovery" of poetry sprang from his contemplation of the slave issue. (Emphasis added, 602n)

Similarly, Betsy Erkkila writes, "When in his notebook Whitman breaks for the first time into lines approximating the free verse of Leaves of Grass, the lines bear the impress of the slavery issue." 6

Martin Klammer, in his provocative work Whitman, Slavery, and the Emergence of Leaves of Grass, uses the "Talbot Wilson" passage as the very fulcrum of his argument. Klammer argues that "Whitman's thinking about African Americans and slavery . . . is, in fact, essential to the development of the poetry of the 1855 Leaves of Grass." ${ }^{\text {" One of the }}$ main pieces of evidence Klammer offers for Whitman's sympathy for the slave is the apparent fact that in the late 1840 s, just at the time that Whitman's politics becomes staunchly Free Soil, "he begins a series of new and unusual poetry experiments in his notebooks-the same poetry that would emerge, revised, eight years later in Leaves of Grass. At the heart of these experiments is a deeply humanitarian concern for the suffering of slaves, completely unlike anything Whitman had expressed in his slavery editorials" (4).

This unusual experiment begins with the first lines of poetry in the "Talbot Wilson" notebook:

I am the poet of slaves and of the masters of slaves

I am the poet of the body

And I am

(NUPM, 67)

Klammer's book is a vital contribution to our understanding of Whitman's complex attitudes toward race, but in this instance, at least, it is in error. These lines were not written in the late 1840s, but in 1854 or 1855. And they are not the earliest experiments leading to Leaves of 
Grass, but the last of a series of notebooks written over a number of years.

The late 1840s dating of the "Talbot Wilson" notebook is the product of the extrapolation of the earliest scholarship on the notebook published by Emory Holloway in 1921. This extrapolation was made necessary by the notebook's disappearance from the Library of Congress's collection when it was moved out of Washington for safe keeping during World War II, as Birney recounts in her article on the notebook's recovery. As a result, for the past fifty years, scholars could study this notebook only through Emory Holloway's transcription of it and a microfilm copy of poor quality made by Floyd Stovall in 1934. While there has been debate about the exact date of the notebook, Edward Grier assigned the date of 1847 (or soon after), and this date has been more or less accepted by scholars since then. Because the poetry in this notebook is so similar to the poetry of the 1855 edition, it has not been possible to speak in any meaningful way of Whitman's poetic development. Inspired by something, Whitman simply blurted out the first sections of "Song of Myself," then spent the next five or so years finishing up the poem. Or so it seemed.

But in 1995, the "Talbot Wilson" notebook resurfaced. ${ }^{8}$ While the Library of Congress Manuscript Division is keeping the actual manuscript off-limits to researchers so as to preserve this fragile document, a copy of it has been scanned and placed on the World Wide Web, transforming it from Whitman's least accessible notebook to the most accessible. Its availability to scholars allows us to make a much more informed argument about its date of composition. ${ }^{9}$ Further, because the error in dating the "Talbot Wilson" notebook has led to confusion in dating the other notebooks, we can now see more clearly the development of Leaves of Grass.

Emory Holloway, in The Uncollected Poetry and Prose of Walt Whitman (1921), dates the notebook to 1847-1850, based on the 1847 date found in the notebook and on the addresses listed inside the front cover. More significantly, Holloway links the dating of the notebook to Whitman's Free Soil activities. Holloway's book was the first attempt to collect all of Whitman's writings in one place, but he does not describe the physical condition of the notebook. His explanation for the 1847-1850 date resides in a half-page footnote placed at the beginning of his transcription of the notebook. The 1847 date, which appears halfway through the notebook (on the fifty-first page of the actual manuscript) is simply mentioned as being contained in the notebook. ${ }^{10}$ The addresses inscribed in the notebook (71 Prince Street, 30 Fulton Street, and 106 Myrtle Ave.) Holloway traces to 1848-1850. The first two date to 1848-1849. Prince Street was Whitman's home during that time, and Fulton Street was the address of the Brooklyn Daily Eagle, where he worked. These two addresses appear on the inside front cover of the notebook (see 
reproduction on the back cover), connected by the word "and." In addition, they both appear to have been crossed out with a single line. Underneath them appears the 106 Myrtle Street address. ${ }^{11}$ According to Holloway, the Spooner \& Teale's Directory for 1849-1850 "gives 106 Myrtle Avenue as the residence of both son and father, the former described as editor of the Freeman" (UPP, 63n). The Freeman was the Brooklyn Weekly Freeman, a Free Soil newspaper Whitman edited during the election of 1848 . Holloway then theorizes:

In the middle of the notebook several pages have been left blank; then come the first attempts at Whitmanesque verse- "I am the poet of slaves and of the masters of slaves." If the latter part of the notebook were written while Whitman was editor of the Free-soil sheet (1848-49), then the theme with which the lyrical composition of the "Leaves of Grass" began would be readily accounted for. (UPP, 63n)

Though Holloway went on to express some doubt as to whether or not the dates were in fact significant, the mis-dating of the notebook was from the first tied to Whitman's Free Soil politics, and the free verse of "Song of Myself" was thus tied to slavery.

Holloway's dating held sway until Esther Shephard, in a long footnote to her 1953 article, "Possible Sources of Some of Whitman's Ideas and Symbols in Hermes Mercurius Trismegistus and Other Works," dated the composition of the notebook around 1854, based on Whitman's own statements in Richard Bucke's biography Walt Whitman, which, according to Edward Carpenter's memoir, Days with Walt Whitman, Whitman had written himself, and his comment to John T. Trowbridge that he had begun Leaves of Grass in 1854, when he read Emerson. ${ }^{12}$ Also, she notes Holloway's comment on the similarity between the "Talbot Wilson" notebook and the "Poem Incarnating the Mind" notebook, which makes reference to the 1854 wreck of the ship San Francisco. Shephard writes:

Whitman may very well have picked up an old notebook in which he had once kept accounts, cut out "the first seven pages," and used the remainder for the composition of prose and poetry for the preface and the body of the book he was working on. If so, the line "(Criticism on Myself)" may have been written not long before the publication date of the first edition. ${ }^{13}$

Applying the theory of Occam's Razor to literary history, Shephard provides a simple, logical explanation of the notebook's history and thus avoids the oddities resulting from a late 1840 s date. Of the seven long notebooks ("long" meaning covering four or more pages in Grier-these are the notebooks that contain significant material that would end up in Leaves of Grass), four are positively dated in $1854 .{ }^{14}$ Thus, if the "Talbot Wilson" notebook was in fact written in 1847, we are left with an unexplained seven year silence. Also, Shephard's thesis explains how 
the material in the "later" notebooks appears to predate the work in the "Talbot Wilson" notebook. Particularly interesting on this point is the fact that in the "Poem Incarnating the Mind" notebook, we seem to see the development of the great "I" of Leaves of Grass, yet that "I" is already fully present in the "Talbot Wilson" notebook.

Despite the explanatory power of Shephard's argument, it was based mostly on a dubious source: the elder Walt Whitman. Whitman is rarely an authoritative source for information about himself, since everything he said about his life and work must be filtered through the way he wanted to be seen at that point. On this very point, in fact, Whitman supplies contradictory information, claiming in the 1872 Preface that "I commenced, years ago, elaborating the plan of my poems, and continued turning over that plan, and shifting it in my mind through many years (from the age of twenty-eight [1847] to thirty-five [1854]) experimenting much, and writing and abandoning much" (NUPM, 53). Also, the evidence available in the mid-1900s-Holloway's transcription and the Library of Congress microfilm - did seem to argue for some kind of literary activity in the notebook in 1847 or 1848 . Consequently, the next major critical work dealing with the "Talbot Wilson" notebook, Grier's 1968 "Walt Whitman's Earliest Known Notebook," established a sort of compromise position. While acknowledging that work on the notebook may have continued up until the mid-1850s, Grier argues that literary work in the notebook begins in 1847, and possibly even 1844. Grier's work is the first thorough investigation of the notebook based on the Library of Congress microfilm, which was discovered shortly before he wrote his article. And, since Grier would come to be the editor of the Notebooks and Unpublished Prose Manuscripts volumes of The Collected Writings of Walt Whitman, much critical work has been based on his arguments for the dating of the notebook.

Beginning by acknowledging that the microfilm "was obviously made carelessly and is of limited reliability," Grier goes on to base his argument for dating Whitman's literary use of the notebook in the late 1840s on four items of evidence: tradition, Whitman's home addresses in the notebook, "the tentative nature of the literary entries," and two memoranda of fiscal transactions in $1847 .{ }^{15}$ The first three, in fact, prove to be lacking in evidentiary power. "Tradition" simply refers to Holloway's 1921 account. The tentativeness of the entries tells us little in and of itself because, as Grier acknowledges, we don't know how quickly Whitman composed at this stage in his career. And the addresses show that the notebook was in use from 1844 through and beyond 1852 (the Myrtle Avenue address, which Whitman sold in May of 1852, is crossed out, suggesting that the notebook was in use after that date). This leaves us with the two fiscal memoranda, which Grier calls the "strongest" evidence for literary use around 1847 . 
Grier claims that both of these 1847 fiscal entries are "preceded and followed by prose [or poetry] of a consistent style" (NUPM, 54). However, in the case of at least one of the entries-page 83 on the Library of Congress Web site (Grier lists this as page 63), which begins "Amount rec'd from Mr. V. A. / 1847"-the interweaving of date and poetry is an illusion caused by the poor quality of the microfilm. Because the actual manuscript was unavailable to him, Grier was unable to consider the implication of an important piece of evidence: the presence of stubs in the notebook (the remnants of cut-out pages), many of which contain numbers, preceding the entries (see, for example, Figure 1 , showing pages 77 and 78 of the notebook). These stubs appear to be the remnants of fiscal ledgers. On page 77, Whitman appears to have written a series of dates down the left-hand column: "Feb," "Ma," and "Ap" are clearly visible. And page 78, the verso side of 77, contains a series of pairs of zeros down the right side of the page. ${ }^{16}$

The presence of stubs, taken together with the fact that the "Mr. V. A." entry appears at the top of the page (see Figure 2), suggests that when Whitman began using the notebook for literary work, he cut all the ledgers out of it, with the exception of two pages where only an inch or two at the top of the page was written on. On the microfilm, the "Mr. V. A." entry appears to be sandwiched between drafts of Whitman's famous "kelson of the creation is love" passage in "Song of Myself." Page 62 of the microfilm leaves off with "And pictures great and small crowd the rail-fence, and hang on its heaped stones and elder and pokeweed, / Is pieture-enough *" while page 63 starts with the "Mr. V. A." entry, and proceeds:

\section{I am the poet of Equality}

*And a mouse is miracle enough to stagger trillions of infidels (NUPM, 71) ${ }^{17}$

Given this evidence, it does indeed appear that Whitman paused from writing to record the information. But in the rediscovered manuscript, we find the page with the "elder and poke-weed" line is number 74, while the "Mr. V. A." page is number 83. The intervening eight pages are stubs with account figures. Whitman left Brooklyn for New Orleans in early 1848, and Grier has conjectured that "Mr. V. A." was Issac Van Anden, the Brooklyn Eagle's publisher and Whitman's employer in 1847, and so Whitman might well have been settling accounts before leaving for New Orleans. This seems likely enough, but in light of the stubs of pages 75-82, instead of a passage of poetry interrupted by a brief fiscal entry, the fiscal entry becomes the last entry in a nine-page ledger. Thus the "Mr. V. A." entry is not in fact "surrounded by verse" (as Grier says [NUPM, 1454]). It is preceded by a lengthy set of figures. It therefore seems highly likely that the passages of poetry were composed after- 


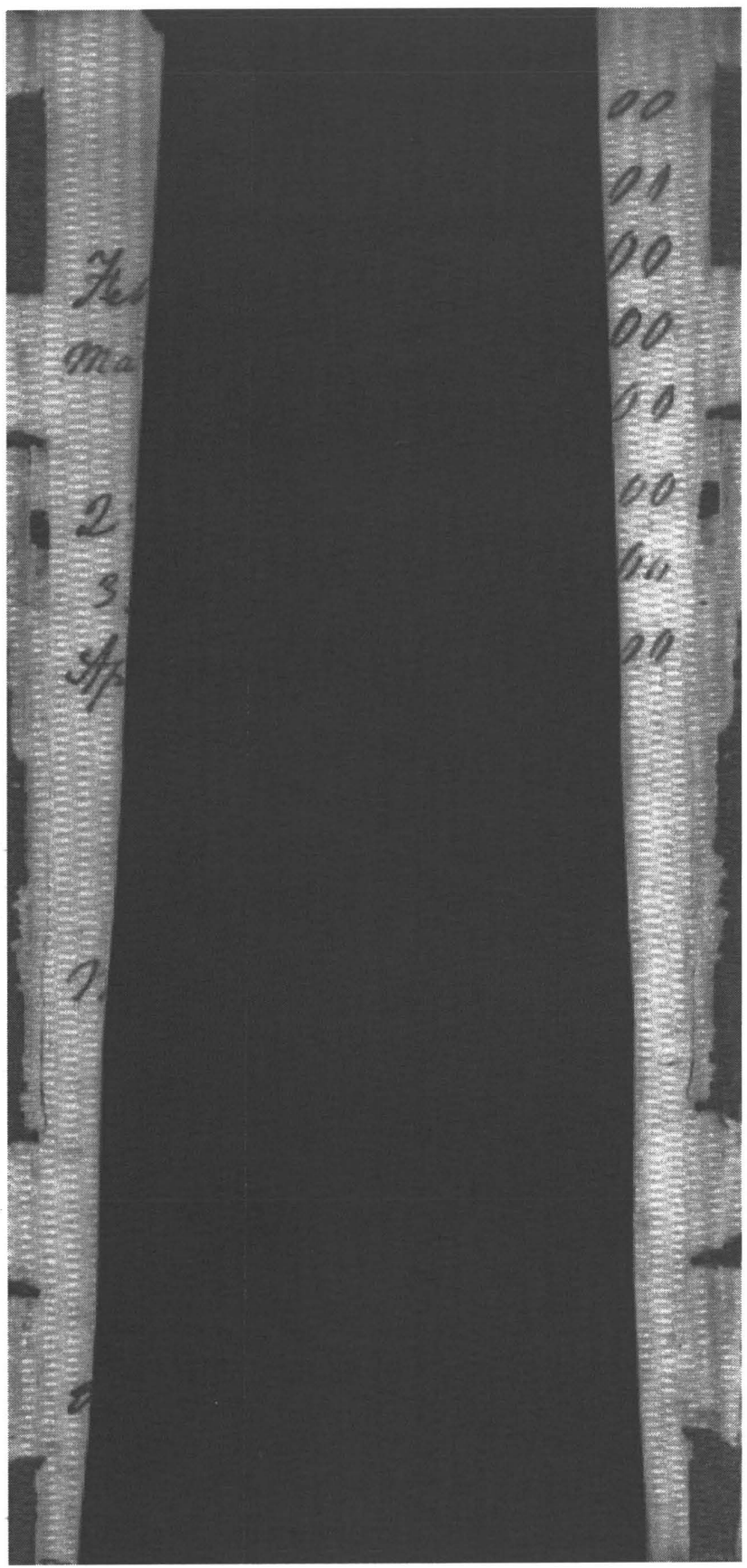

Figure 1. Stubs of pp. 77-78 (recto and verso) of Whitman's "Earliest" Notebook. 


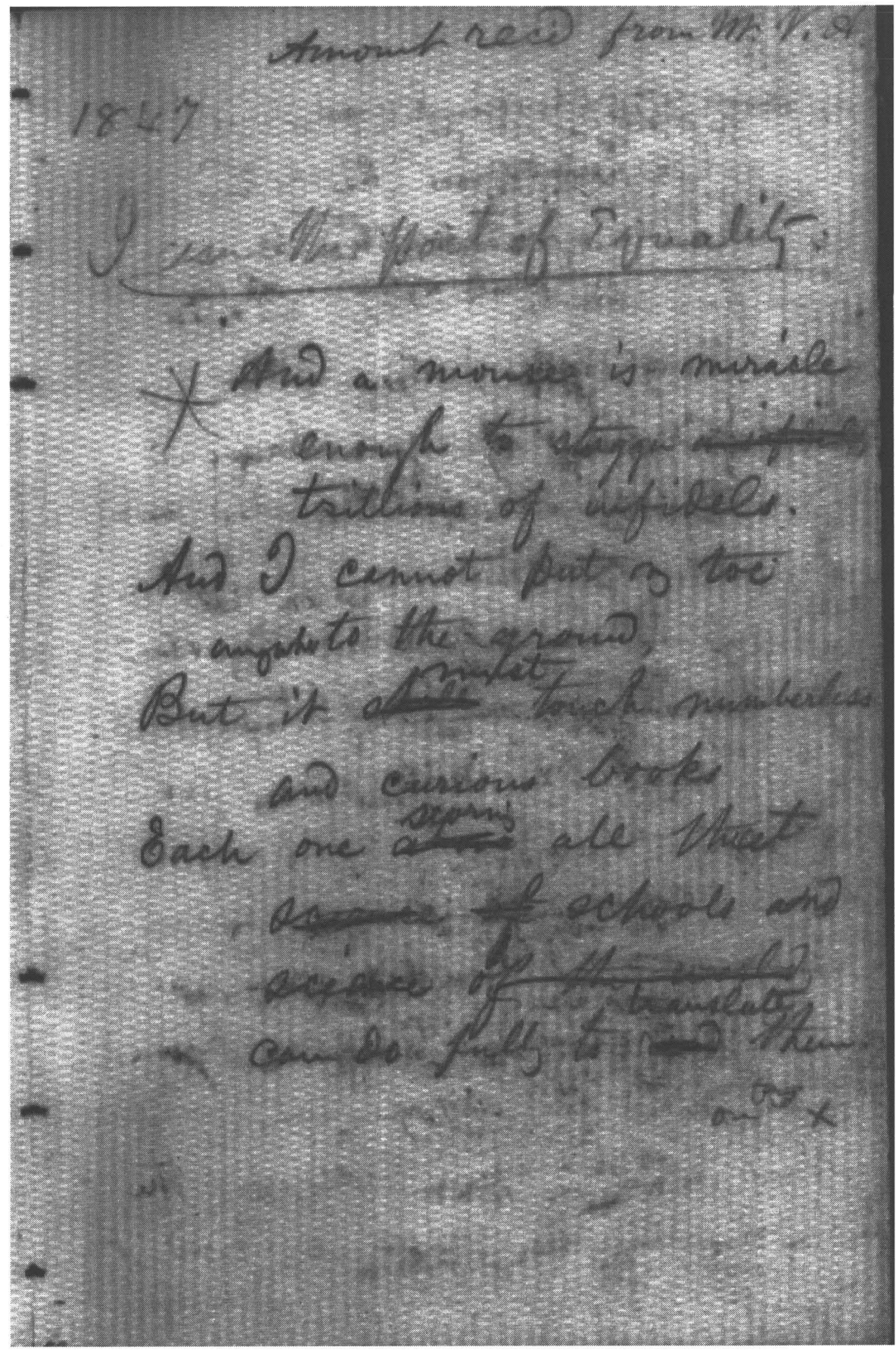

Figure 2. Page 83 of Whitman's "Earliest” Notebook. 
not at the same time as-the "Mr. V. A." entry. If external evidence cannot accurately date the "Talbot Wilson" notebook, then we are left with internal evidence: the thematic and stylistic contents of the notebooks themselves. For all the discussion of the dating of the notebooks, this major source of evidence has gone largely unexamined. Indeed, the largest problem with an 1840s date for the "Talbot Wilson" notebook may be the fact that, if we accept that date for the notebook, then, in Henry Seidel Canby's phrase, "most of all that Whitman was to be, was to believe, and was to say is at least suggested by these jottings," whereas the "later" notebooks, like "Poem Incarnating the Mind," and "The Regular Old Followers" (both positively dated 1854), appear to be written by someone working towards the maturity of the "Talbot Wilson" poetry. ${ }^{18}$ Are we to believe that Whitman was inspired in 1847 , promptly forgot his vision, and spent the next seven years working back to it? Unlikely. What is more probable is that the "Talbot Wilson" notebook was in fact a much later work, as Birney and Shephard have argued.

Recognizing that the "Talbot Wilson" notebook is a later work invites us to reassess it, especially its statements about race and slavery. What we discover is that slavery, in fact, plays a very minor role in the notebook, that Whitman is far more concerned with issues of ownership and the soul, and that discussions of slavery, when they do appear, seem to be as much connected to working-class wage-slavery rhetoric as to Free Soil anti-chattel-slavery rhetoric.

Whitman mentions slavery only three times in the notebook, none of which shows much humanitarian concern for the slaves. Instead, slavery is invoked in each passage more for its metaphorical power. The first instance is a prose version of the "poet of slaves" passage, in which Whitman proclaims that the poet "says indifferently and alike How are you friend? to the President in the midst of his cabinet, and Good day my brother, to Sambo, among the blaek slaves hoes of the sugar field, and both understand him and know that his his speech is well for his right.- " (NUPM, 61 / LC, 36). ${ }^{19}$ The second instance is the "poet of slaves" passage. And the final mention of slavery is indirect: claiming he does not believe in sin, the poet's spirit steps "among murderers and cannibals and traders in slaves" (NUPM, 73 / LC, 90). What is remarkable about each of these passages is their matter-of-fact acceptance of slavery. Speaking "indifferently" to "Sambo" in the sugar fields is a far cry from expressing any real concern over the fate and condition of African American slaves. Instead, Whitman seems to be using this image of slaves for the same purpose that Ed Folsom suggests he uses the slave and master imagery in the "poet of slaves" passage, to identify "the poles of human possibility-the spectrum his capacious voice would have to cover-as they appeared to him at mid-nineteenth century."20 
Even the "poet of slaves" passage does not seem to be such a bold declaration about chattel slavery itself. Instead, a close examination of the revisions Whitman makes to these lines reveals that, while he first invokes the slave/master binary, both revisions minimize the focus on slavery. Whitman first writes:

I am the poet of slaves and of the masters of slaves

I am the poet of the body

And I am

(LC, 68)

But without even completing the thought, Whitman begins to de-emphasize the slavery metaphor, striking it out and placing the body/soul binary before the slave/master binary, and emphasizing, with the word "thus," that he is a poet of slaves and masters because he is the poet of the body and the soul:

I am the poet of the body

And I am the poet of the soul

Thus the slaves are mine and the masters are equally mine

And I will stand between the masters and the slaves,

And I enter into both, and both shall understand me alike.

This passage does not free slaves; it enslaves masters. He then revises the passage about slaves again, replacing the third line with: "I go with the slaves of the earth equally with the masters" (LC, 68).

These revisions suggest a writer uneasy about the power of his metaphor. Klammer and Erkkila have read Whitman's revisions of these passages as a sign of his inability to mediate in fact between master and slave. ${ }^{21}$ They assume that Whitman is primarily talking about chattel slavery. But "slavery" was a powerfully complex word in the mid-1800s, and while its meanings are ultimately grounded in chattel slavery, it served a variety of purposes. Thoreau, in Walden, for example, declares "It is hard to have a Southern overseer; it is worse to have a Northern one; but worst of all when you are the slave-driver yourself." 22 And refusing his nomination to the Liberty Party ticket, Henry Wadsworth Longfellow wrote to John Greenleaf Whittier, "though a strong antislavery man ... I shall rejoice in the progress of true liberty, and in freedom from slavery of all kinds; but I cannot for a moment think of entering the political arena." 23 And James M. McPherson has shown that during the Civil War, even Confederate soldiers could use the term "slavery," without irony, to describe the state they believed Union victory would bring them. One South Carolina captain wrote in 1862, "Sooner than submit to Northern Slavery, I prefer death" (49). As McPherson explains, "those [Confederate] soldiers were using the word slavery in the same sense that Americans in 1776 had used it to describe 
their subordination to Britain" (50). Further, McPherson found only one occasion when a soldier acknowledged any inconsistency in a slaveholding nation declaring itself to be fighting for liberty and against its own enslavement (50-51). While each of these uses of slavery is ultimately a metaphor grounded in chattel slavery, they all indicate the broad array of referents the term "slavery" had in the mid-nineteenth century.

It is likely, as Klammer and Erkkila suggest, that Whitman did indeed feel unable to truly mediate between Southern masters and slaves, but in this passage the poet's uneasiness more likely stems from his recognition of the unintended meanings of his words (these are drafts, after all, not carefully revised, published works). It is possible that when Whitman first declares himself the poet of slaves and of the masters of slaves, he had in mind the generic notion of slavery, but only as the implications became clear to him did he edge away from the metaphor, and then abandon it entirely. He does not, in other words, abandon the metaphor because he recognized his inability to mediate between masters and chattel slaves, but because, like the Southern soldiers in McPherson's study, he never intended to refer to chattel slavery in the first place.

What is significant about the "I am the poet of slaves and of the masters of slaves" line is that it did not make it into Leaves of Grass. What does appear in the poem later entitled "Song of Myself" are the lines:

I am the poet of the body,

And I am the poet of the soul. (46)

While these lines occur in a section rife with Whitman's rhetoric of democracy and the body beautiful ("In all people I see myself," he declares twenty-one lines earlier), there is no overt discussion of race or slavery in this section of "Song of Myself." The closest fit comes in the lines quoted by M. Wynn Thomas in his discussion of the soul in "A Song for Occupations," where the poet proclaims the opposite: "Neither a servant nor a master am I." ${ }^{24}$ According to Thomas, Whitman, in "A Song for Occupations" and other early Leaves of Grass poetry, invokes the term soul "to communicate to others his conviction that they have allowed themselves to be devalued, silently demoralized by accepting the current market prices for their lives and by relying on the crude descriptive terms of social classification for their self-identity" (13). So the "soul" serves not "as part of a vapid vocabulary of spiritual transcendence" but as an extra-economic vision of the self (13).

Thomas's ideas here help us to make sense of the roughly fifty pages of prose that precede the poetry in the notebook. What this notebook shows us is that Whitman was deeply engaged in trying to define for America a locus of identity outside the economic realm. In a rough 
sense, Whitman does for the laborer what Margaret Fuller's Woman in the Nineteenth Century does for women-adapts Emersonian self-reliance to specific political and economic circumstances. Where Fuller shows how patriarchal society prevents women from becoming self-reliant and developing "an original relation to the universe," ${ }^{25}$ Whitman shows how the laborer too is excluded from access to any kind of transcendent vision by the economic and social structure of the emerging industrial capitalist economy.

Whitman begins the notebook with a series of passages describing his b'hoy-influenced version of the American character, an early type of Thomas's extra-economic soul. From that point, Whitman moves through a series of discussions of the nature of the soul, its relation to the material world and other souls, and the poet's role as mediator between souls. Finally, this exploration of the soul brings him back to class issues in the long passage on ownership that precedes the poetry. The poetry that follows, much of which is later found in "Song of Myself," is Whitman's attempt to work out his own version of Emerson's essay "The Poet," in which the poet acts to define and cement the culture.

The notebook opens with Whitman urging all the nation's youths to adopt the working-class b'hoy pose:

Every American young man should carry himself with the finished and haughty bearing of the greatest ruler and proprietor-for he is then a great ruler and proprietor- the the greatest. (NUPM, 56 / LC, 18)

The b'hoys, who mimicked upper-class conventions, had themselves already fashioned a limited kind of extra-economic identity (that is, the b'hoy pose, in aping the upper class, pretended that economics did not matter). ${ }^{26}$ But Whitman freed the b'hoy pose from its dependence on upper classes. Instead of a satirical pose, Whitman packages its essential independence into a self-reliant American character, which is to be "illimitably proud, independent, self-possessed and generous and gentle.It is to accept nothing except what is equally free and eligible to any body else" (NUPM, 56 / LC, 17).

The extra-economic soul is the wellspring of this character, and in Whitman's explorations of the soul on pages $26-41$ of the notebook, we see his vision of Leaves of Grass begin to coalesce. Here in the notebooks, as in Leaves of Grass, the soul is manifested in the body:

The effusion or corporation of the soul is always under the beautiful laws of physiology-I guess the soul itself can never be any thing but great and pure and immortal; but it is a makes itself visible only through matter - a perfect head, and bowels and bones to match. ... (NUPM, 58 / LC, 30)

The body as the vessel of the soul will become the basis for democratic 
society in Leaves of Grass. ${ }^{27}$ But Whitman hasn't made that leap yet. $\mathrm{He}$ is stymied by "wickedness," which he supposes, in an unfinished passage, "is most likely the absence of freedom and health in the soul" (NUPM, 65 / LC, 33). But souls cannot communicate, so the poet comes along to mediate between all souls, and it is the poet who "has the divine grammar of all tongues," including those bound by the absence of freedom. Therefore, the poet is the poet of the slaves (those who suffer the absence of freedom) and the masters of slaves (those who inflict the absence of freedom on others). Chattel slaves are certainly a part of this group and will become important to Whitman as he develops these ideas into particular passages of poetry, but the occasion of these lines is not chattel slavery but rather Whitman's own general concern with absence of freedom in the American character. It is toward the end of this discussion that we find the first reference to slavery, the "Sambo" passage. The poet, "says indifferently and alike How are you friend? to the President in the midst of his cabinet, and Good day my brother, to Sambo among the blaek slaves hoes of the sugar field, and both understand him and know that his speech is well right.= right, for his" (NUPM, 61 / LC, 36). This is the role- the joiner of the whole - that Whitman will adopt in the poetry of this notebook, and it is in that role that he will declare himself "the poet of slaves and of the masters of slaves," but at this point, his vision of unity is simply sentimental. Not until the exploration of ownership on pages 50-66 does his vision become a challenge to hierarchic power structures.

In this discussion of ownership, Whitman takes transcendentalist notions of the Over-soul and fuses them with working class anxieties about the growing economic stratification in New York in the wake of the breakdown of the artisanal system of labor. In the first chapter of Nature, Emerson describes the limits of ownership and the poet's role in integrating "all the parts" of the world into a coherent whole:

The charming landscape which I saw this morning is indubitably made up of some twenty or thirty farms. Miller owns this field, Locke that, and Manning the woodland beyond. But none of them owns the landscape. There is a property in the horizon which no man has but he whose eye can integrate all the parts, that is, the poet. This is the best part of these men's farms, yet to this their warranty-deeds give no title. (1:9)

Whitman's statements on ownership, however, are far more radical than Emerson's. While Emerson notes the limits of warranty-deeds, he does not dispute that Miller, Locke, and Manning do own their portions. But Whitman expands Emerson's vision beyond landscape to denounce all ownership:

The orted ignorant man is demented with the madness of owning things - of having like by warranty deeds and lawful possession, and with perfeet court records, the right to mortgage, sell, tispense with give away or raise money on certain possessions.-But 
the wisest soul knows that - nothing in the vast universe no object can really be owned by one man or woman any more than another. (NUPM, 59 / LC, 52)

And a few pages later he writes, "The ignorant think that to the entertainment of life, you are they will be admitted by a ticket or check, and the aim of dream of their existence is to get the money that they may buy this env wonderful card" (NUPM, 60 / LC, 57). In each of these passages, Whitman particularly rejects the power of legal documents to confer ownership. This rejection reflects Whitman's anxiety over the growth of the wage-labor system and what he saw as the continued disenfranchisement of the artisan laborer. Those professions that depend on paper are suspect, while those grounded in labor are celebrated, an ironic position for a journalist and would-be poet, but one that is consistent with Whitman's portraits of workers in action in Sections 10-13 of "Song of Myself": the blacksmiths at the forge, the black teamster, the butcher boy, even the runaway slave and the woman who imaginatively cavorts with the twenty-eight bathers, are all defined by actions, not by what they own. ${ }^{28}$

And in the last prose passage before Whitman declares himself in verse the poet of slaves, he rejects not slave owners, but professors and capitalists:

I will not descend among professors and capitalists, and goon -I will turn up the ends of my trowsers tup around my boots, and my cuffs back from my wrists, and go among the rough with drivers and boatmen and men who that catch fish or hoe eorn work in the field. I know that they are sublime (NUPM, 67/ LC, 65)

The rejection of professors together with capitalists also recalls "A Song for Occupations," in which politics, wealth, and education are the triumvirate that the speaker rejects in favor of the soul: "Is it you that thought the President greater than you? or the rich better off than you? or the educated wiser than you?" $(C P C P, 90)$. It is in this context that Whitman declares himself the poet of slaves and of the masters of slaves.

But how does Whitman make the jump from a discussion of ownership that focuses on the class debates of New York and Brooklyn to a comment on slavery? Rather than abolitionist or even free-labor opposition to slavery, what these passages reflect is the wage-slavery rhetoric of the fading artisanal labor movement in the mid-1800s. As I have already suggested, "slavery" was a problematic term for Whitman in the 1850 s, as it was for many Americans. Since colonial days, the term "slavery" had been employed to describe any loss of political or economic freedom..$^{29}$ As wage labor became established in the early to mid-1800s, many workers feared it as a loss of freedom. As Eric Foner explains, "the metaphor of wage slavery ... drew on immediate grievances such as low wages, irregular employment, the elaborate and arbitrary work rules of the early factories, and the use of conspiracy indictments to 
impede union organizations" (60). The artisan laborers did not see people as free unless they owned the means to produce goods they could sell. Thus a blacksmith without a forge and anvil, or a carpenter without a saw and hammer, was not truly free and independent. This view is distinct from that of abolitionists, who saw freedom simply as self-ownership. ${ }^{30}$ Bruce Laurie dates the association of wage labor and slavery as early as the 1836 strike of the Lowell mill women (the same women who would go on to write The Lowell Offering in the 1840s). Their strike song declared:

Oh! Isn't it a pity, such a pretty girl as I-

Should be sent to the factory to pine away and die?

Oh! I cannot be a slave,

I will not be a slave,

For I'm so fond of liberty

That I cannot be a slave. ${ }^{31}$

And Orestes Brownson, co-editor of the Democratic Review while Whitman was publishing in it in the early 1840 s, wrote in his 1840 essay "The Laboring Classes," "If the slave has never been a free man, we think, as a general rule, his sufferings are less than those of the free laborer at wages." ${ }^{32}$ Brownson described wages as "a cunning device of the devil, for the benefit of tender consciences, who would retain all the advantages of the slave system, without the expense, trouble, and odium of being slave-holders" (370). Tammany Hall politician Mike Walsh made a political career out of equating the situation of wage laborers to that of chattel slaves. In 1845, in his newspaper, Walsh declared that the wage labor system had turned previously free artisan workers into slaves:

Demagogues tell you that you are freemen. They lie-you are slaves, and none are better aware of the fact than the heathenish dogs who call you freemen. No man devoid of all other means of support but that which his labor affords him can be a freeman, under the present state of society. He must be a humble slave of capital, created by the labor of the poor men who have toiled, suffered, and died before him. ${ }^{33}$

But the wage-slavery rhetoric of Walsh had grown stale by the mid1850s. As David Roediger has shown, the presence of slavery in America had a somewhat contradictory impact on the attitudes of free labor toward wage labor. While on the one hand, the nearness of slavery provided a ready metaphor for the condition into which laborers did not want to fall, on the other hand, as the wage-labor economy developed, many laborers could not ignore the differences between their own position and that of the chattel slave: "The existence of slavery ... gave working Americans both a wretched touchstone against which to measure their fears of unfreedom and a friendly reminder that they were by comparison not so badly off." ${ }^{34}$ As the power of wage slavery rhetoric 
dimmed in the early 1850 s, Walsh himself, elected to the House of Representatives in 1852, became more of a pro-slavery Northerner than a champion of labor (Wilentz, 333). And as the wage-labor system became more entrenched, many workers became less ambivalent about capitalism. While many laborers prospered under the system, many of those who didn't held out hope that they too could eventually cash in. Wilentz writes of Walsh:

Alone of all the prominent local political figures of the early and mid-1840s, [Walsh] spoke in an unvarnished language of class conflict, thrusting the labor theory of value into his listeners' faces, attaching the cause of the 'wage slaves' to that of the social democracy. If his radicalism did not extend to the question of slavery and race and if he ultimately led his followers into a disastrous political alliance [with Southern slave holders], he also brought an anti-capitalist variant of artisan republicanism out of the workshops and meeting halls and into the streets, to challenge the moral reformism and nativism of the 1840s and to bridge the gap between labor radicalism and Bowery republicanism that the unionists of the 1830 s had never fully overcome. The achievement fell far short of Walsh's original promises. The message would help vitalize a new labor movement, even as Walsh himself began to drown in party politics and liquor. (334-335)

Wilentz could have added that Walsh's message would also vitalize the young Walter Whitman. David S. Reynolds notes that Whitman contributed a poem to the first edition of The Subterranean, and Reynolds even suggests that "Whitman's aggressive, sometimes hypermasculine persona in Leaves of Grass seems a tempered version of Walsh's selfconsciously virile pose" (103). Whether or not Walsh's brash public persona served as a model for Whitman's literary persona, Whitman's ties to Walsh are evidence of the poet's close contact with a tradition in radical politics that regularly employed slavery as a trope for class-based concerns that had little to do with the conditions of the men and women held in bondage in the southern half of the United States.

This willingness to employ the rhetoric of slavery despite his own uneasy indifference to the plight of chattel slaves themselves is evident in some of the earlier notebooks. When we examine the draft version of some of Whitman's most famous images of African Americans in Leaves of Grass, we discover that the earliest images of slaves are one-dimensional. Far from reflecting Whitman's humanitarian sympathy for slaves, these earliest images reduce African Americans to powerless, voiceless figures employed as ciphers for Whitman's primary concerns in the early notebooks: power and ownership. It is only when Whitman develops his mature poetics, in which identity is based on action, rather than on static categories such as race and class, that Whitman's blacks attain the life and individuality that marks the best work of "Song of Myself." Two passages in particular allow us to see how Whitman inscribed and revised race in his early notebooks and in Leaves of Grass: one passage in which Whitman transforms a black man trapped in a collapsed building 
into the dying white firefighter of "Song of Myself," and the other in which he describes a curiously raceless slave on the auction block in "I Sing the Body Electric."

The earliest mention of African Americans in the pre-Leaves of Grass notebooks is found in the "Autobiographical Data" notebook in the passage about the man- "black Caesar"-trapped in the collapsed building:

Years ago I formed one of a great crowd that rapidly gathered where a building had fallen in and buried a man alive.-Down somewhere in those ruins the poor fellow lurked, deprived of his liberty, perhaps dead or in danger of death.- How every body worked! How the shovels flew! And all for black Caesar-for the buried man wasn't any body else. (NUPM, 215-216) (N5 $^{35}$

When compared with the "Song of Myself" version of this scene, we see an important distinction between this Whitman and the Whitman of 1855. Namely, the 1855 poet is concerned with the humanity of the figure, with establishing identification between speaker and victim, whereas the notebook passage emphasizes difference. Accordingly, Whitman revises the race of the trapped figure from black, in the notebook, to white in "Song of Myself." 36 In "Song of Myself," the passage recounts the death of a firefighter crushed in a building:

I am the mashed fireman with breastbone broken .... tumbling walls buried me in their debris,

Heat and smoke I inspired .... I heard the yelling shouts of my comrades,

I heard the distant click of their picks and shovels;

They have cleared the beams away .... . they tenderly lift me forth.

I lie in the night air in my red shirt .... the pervading hush is for my sake,

Painless after all I lie, exhausted but not so unhappy,

White and beautiful are the faces around me .... the heads are bared of their firecaps,

The kneeling crowd fades with the light of the torches. $(C P C P, 65)$

In this section, Whitman speaks as the fireman. The emphasis here is on the physical sensations - the broken bone, the tumbling walls, heat and smoke. Death, in this passage, is "lucky"-the fireman is honored, free of pain, surrounded by beautiful "white" faces. Body and soul are not a dichotomy, but rather two parts of a whole. The preposition "with" in the final line is ambiguous; does the crowd fade at the same time as the torches? Or does the approach of the torches (carried by spiritual guides? angels?) cause the crowd to fade? We don't know exactly, and it is this weaving of soul and body that gives passages like this in "Song of Myself" their power and subtlety.

The notebook version, however, lacks this ambiguity. Instead, the story is a parable about freedom. The "poor fellow" is "deprived of his 
liberty," and so everyone works to save him even though he is only "black Caesar." Rhetorically, there is no identification with the "black Caesar." Instead, the man is clearly an "other," set off from the crowd by both race and fallen timbers. Whitman employs blackness to highlight the white crowd's humanity and goodness. To accomplish this, the poet need not emphasize the trapped man's humanity. Indeed, he consciously $d e$-emphasizes it with the laughing reference to him as "Caesar." And within the context of the piece, this de-emphasis serves to heighten the goodness and concern of the crowd. Whitman is subtly implying that had the crowd striven to save a white man, self-interest or some kind of group identity could have been at work. But the black man is so wholly an outsider that the crowd's actions can stem only from altruism-goodwill, sacrifice, and community, traits that the trapped man may momentarily benefit from, but never partake in. The 1855 version will emphasize these same traits-the selflessness of the "mashed fireman," the goodwill and community of the mourners-but will do so without employing static racial stereotypes.

Even more challenging to our understanding of Whitman's racial attitudes is the notebook version of one of the most famous depictions of African Americans in Leaves of Grass, the scene describing the slave on the auction block in "I Sing the Body Electric." Far from the vitality and individuality the speaker confers on the body of the black man in the poem, the notebook version almost seems to avoid race as it attempts to use the image of the slave as a purely economic image.

In the 1855 version of the poem, Whitman offers the reader the image of the attractive white patriarch, followed by an abstract discussion of the sacred nature of the body. These passages seduce the presumably white reader to identify with the patriarch, an identification grounded in the commonality of the body. But then he offers the reader the vivid, sensuous image of the black man and woman on the slaver's auction block. The white reader can reject identification with the slave only at the expense of rejecting identification with the patriarch. This is Whitman at his most deliciously devious. ${ }^{37}$

But the notebook version of the auction scene (found in the "Memorials" notebook, NUPM, 147) differs from the final version in three important ways that emphasize economics and de-emphasize race. First, where the main focus of the final version is the body of the man on the auction block ("Flakes of breastmuscle, pliant backbone and neck, flesh not flabby, goodsized arms and legs" [CPCP, 123]), the notebook version makes no mention of physique:

How much for the man

A Man at Auction

$\mathrm{He}$ is of ? value

For him the earth lay preparing billions of years without one animal or plant

For him the things of the air, the earth and the sea 
He is not only himself

$\mathrm{He}$ is the father of other men who shall be fathers in their turn. (NUPM, 147)

The man in this passage is a generalized man, more a concept ("Man") than a particular person.

Second, where the final version dismisses the question of value right away ("Whatever the bids of the bidders they cannot be high enough for him" [CPCP, 123]), the notebook version takes the question more seriously:

How much for the man

$\mathrm{He}$ is of ? value

It is clear that, just as in the final version, the value of the man is exceedingly high, but in the final draft, the question of value acts as an excuse or occasion to describe the body in detail. In the notebook version, however, the question of value is the important issue.

These two differences embody the differences between the Whitman of the notebooks and the Whitman of the 1855 Leaves of Grass: the former is primarily concerned with economic issues, particularly inequalities which threaten to divide the nation, whereas the latter focuses on the human body as a fundamental locus of identity and union. It is the shift from the poetics of economics to the poetics of the body that brought about the third difference between these two passages: the fact that the notebook version seeks to avoid racial imagery whereas the 1855 version confronts it directly.

In "I Sing the Body Electric," the race of the man on the auction block is central to the poem; the contrast with the patriarch ensures that the reader understands that this Adonis on the auction block is a black man. In the notebook, however, there is no mention of race, or even of slavery. Of course, we assume the man is black because only blacks were auctioned, but the absence of any racial imagery suggests that Whitman is almost trying to sidestep the question of race. In the 1855 version, however, the poet is unambiguous about the man's racial status: "A slave at auction!" he declares in the opening lines of the passage (emphasis added, CPCP, 123). Further, there is an auctioneer, and the speaker helps him with his "business," calling to the gathered crowd, "Gentlemen look on this curious creature" (123). At this point, the abstract "Man at Auction" of the notebook has become clearly and unambiguously an African-American slave being sold at public auction.

But at the same time as Whitman forces us to look closely at this black body, he calls the very notion of race into question, dismissing skin color as a (literally) superficial feature: "Examine these limbs, red black or white . . . . they are, very cunning in tendon and nerve; / They shall be stript that you may see them" (123). Then he turns and extends his challenge to racial identity to the reader, asking: 
How do you know who shall come from the offspring of his offspring through the centuries?

Who might you find you have come from yourself if you could trace back through the centuries? (123)

The consequence of this passage is to transform race from a static identity to a dynamic one. Just as the emphasis on action allows laborers to circumvent the rigid boundaries of class in Whitman's poetry - to form bonds of identification that transcend those divisive images - so too in this poem Whitman's singing the body electric softens racial identities enough to allow white readers to form bonds of identification with African Americans. Indeed, this kind of racial indeterminancy has already been foreshadowed in Whitman's reference to the "clear brown skin" of the white patriarch $(120) .^{38}$

None of this fluidity is present, however, in the notebook. Instead, the abstract image of the man at auction is useful to Whitman because it combines the themes of ownership and equality. To broach the issue of race, however, would be to open a discussion Whitman had, as yet, shown little interest in. When Whitman criticizes the Fugitive Slave Law in "Autobiographical Data," he criticizes the fact that it dictates to local people. He even goes so far as to concede that the Constitution requires the return of runaway slaves, "that we all know," but "we hold the right to decide how to do it . . . without any violent intrusion from abroad" (NUPM, 214). And in the only prior mention of slavery in "Memorials," Whitman's concern is wholly in line with Free Soil politics:

Everyone that speaks his word for slavery is himself the worst slave-the spirit of a freeman is not light enough in him to show that all the fattness [sic] of the earth were bitter to a bondaged neck. (NUPM, 142)

The Free Soilers had, on the whole, little interest in the conditions of blacks. They opposed slavery because they saw slave labor as a threat to wage labor, and ultimately, as a brake on the economic potential of the United States. Indeed, much of the success of the Free Soil party lay in the fact that it was able to separate the anti-slavery cause from the cause of political and social equality for blacks. ${ }^{39}$ That Whitman still strongly identified with the Free Soilers when he wrote the auction passage in "Memorials" is made clear in a line just prior to it. Underneath the heading "My final aim," Whitman writes, "To concentrate around me the leaders of all reforms - transcendentalists, spiritualists, free soilers" (NUPM, 147). Whitman, as he wrote these lines, was a long way from the poet who, in "Talbot Wilson," would write, "I am the poet of slaves and of the masters of slaves" (NUPM, 67). But he was farther still from the poet who would nurse the runaway slave in "Song of Myself," "putting plasters on the galls of his neck and ankles" $(C P C P, 35)$. The pieces were in place: he had begun to articulate a democratic poetics that might 
accomplish his goal of a truly unified America; he had a firm sense of the sacredness of the soul and the connection between its health and a healthy democracy; and he was moving toward the recognition of the threat that slavery was to democracy. ${ }^{40}$ But he did not yet understand how to make the pieces cohere. That coherence would come only when he recognized the importance of the body, something that would not fully appear until the final notebooks: "Poem incarnating the Mind" and "Talbot Wilson." Until that happened, Whitman's images of slaves would remain one-dimensional, used more as metaphor than as literal image.

By the time Leaves of Grass is published in 1855, the wage-slavery rhetoric had disappeared from Whitman's poetry and was replaced by a genuine concern for the slave alongside his concern for laborers and all other Americans. We see this concern in the many portraits of blacks that populate the 1855 poetry: the escaped slave who arrives at the speaker's door; the teamster, "the picturesque giant" $(C P C P, 37)$ who is almost a black twin of the picture of the author in the frontispiece; ${ }^{41}$ and the slaves on the auction block in "I Sing the Body Electric"portraits that are as individual and fully-fleshed as any in the 1855 poetry. In at least one pre-Leaves of Grass notebook manuscript, we can see Whitman's attitudes shifting. Instead of using slavery as a trope for ownership, here the slave and "black men" become included in the list of the oppressed along with the laboring poor. In "The Noble Soul," dismissing the notion of ownership, Whitman writes:

Meanwhile it is the endless delusion of big and little smouchers, in all their varieties, whether usurping the rule of an empire, or thieving a negro and selling him,- - whatever and whichever of the ways that legislators, lawyers, the priests and the educated and pious, prefer certain advantages to themselves, over the vast retinues of the poor the laboring, ignorant man, black men, sinners, and so on-to suppose they have succeeded when the documents are signed and sealed, and they enter in possession of their gains. (NUPM, 121-122)

In this note, when Whitman talks about ownership, he does not use images of slaves as a trope or a metaphor-he talks about them as people.

\section{Louisiana Tech University}

\section{NOTES}

1 Walt Whitman, Notebooks and Unpublished Prose Manuscripts, ed. Edward F. Grier (New York: New York University Press, 1984), 67. Hereafter NUPM.

2 Alice Birney, "Missing Whitman Notebooks Returned to Library of Congress," Walt Whitman Quarterly Review 12 (Spring 1995), 217-229.

3 M. Wynn Thomas, The Lunar Light of Whitman's Poetry (Cambridge: Harvard University Press, 1987); Joseph Jay Rubin, The Historic Whitman (University Park: Penn- 
sylvania State University Press, 1973); Hughes is quoted in George B. Hutchinson, "Langston Hughes and the 'Other' Whitman," in The Continuing Presence of Walt Whitman, ed. Robert K. Martin (Iowa City: University of Iowa Press, 1992), 17.

4 Grier, "Walt Whitman's Earliest Known Notebook," PMLA 83 (October 1968), 1453-1456.

5 David S. Reynolds, Walt Whitman's America: A Cultural Biography (New York: Knopf, 1995), 117.

6 Betsy Erkkila, Whitman the Political Poet (New York: Oxford University Press, 1989), 50 .

7 Martin Klammer, Whitman, Slavery, and the Emergence of Leaves of Grass (University Park: Pennsylvania State University Press, 1995), 3.

8 For an account of the notebook's return, see Birney, 217-220.

9 As Birney notes, the manuscript has been scanned and placed online in the American Memory section at <http://lcweb.loc.gov>. The exact address as of June 2002 is <http://memory.loc.gov/ammem/wwhtml/wwhome.html>.

10 In The Uncollected Poetry and Prose of Walt Whitman, ed. Emory Holloway. (Gloucester, MA: Peter Smith, 1972), 63n. Hereafter UPP.

11 A JPEG image of this page is available at the Library of Congress site. It is listed as "Front Cover Verso."

12 Trowbridge's account of his conversation with Whitman, "Reminiscences of Walt Whitman," is available in Whitman in His Own Time, ed. Joel Myerson (Iowa City: University of Iowa Press, 2000), 172-174. It is worth noting that the impression that Trowbridge gives here, that Whitman discovered Emerson in 1854 as he was employed "as a carpenter . . . building with his own hands and on his own account small and very plain houses for laboring men" (Trowbridge, 173), is not quite accurate. Whitman certainly heard Emerson deliver a version of "The Poet" in March of 1842, since he wrote a review of it in the New York Aurora (Walt Whitman of the New York Aurora, ed. Joseph Jay Rubin and Charles H. Brown [State College, PA: Bald Eagle Press, 1950], 105).

13 Esther Shephard, "Possible Sources of Some of Whitman's Ideas in Hermes Mercurius Trismegistus and Other Works," Modern Language Quarterly 14 (March 1953), $67 \mathrm{n}$.

14 These four notebooks dated to 1854 are "You Know How the One" (NUPM, 124), "I Know a Rich Capitalist" (128), "The Regular Old Followers" (113), and "Memorials" (138). For a discussion of the dating of these notebooks, see my doctoral dissertation, Art and Argument: The Rise of Walt Whitman's Rhetorical Poetics, 1838-1855, University of Massachusetts, Amherst, 1999 (Ann Arbor: UMI, 2000; 9950161). I date the first three notebooks to 1854-1855 (159-187). I argue that Whitman used each of these three notebooks to explore a particular theme, much in the way that the "Talbot Wilson" notebook explores ownership. Whitman uses "I Know a Rich Capitalist," for example, to develop his cosmology and theory of love. "Memorials," however, serves a different function; it is more of a journal kept over a series of years, beginning in 1853 and ending in 1855 (147-148).

15 Grier, "Walt Whitman's Earliest Known Notebook,” 1453-1455.

16 The pages in question are numbered 74-83 on the Library of Congress site. 
17 An image of this page from Stovall's photostat is printed in Grier's Notebooks and Unpublished Prose Manuscripts between pp. 245 and 246. Given the poor quality of the photostat, it is easy to see how the date appeared to be synchronous with the poetry.

18 Henry Seidel Canby, Walt Whitman, An American: A Study in Biography (Boston: Houghton Mifflin, 1943), 88.

19 For the remainder of this article, quotations from the "Talbot Wilson" notebook will be cited using references to Grier's Notebooks and Unpublished Prose Manuscripts (NUPM) followed by the page number of the notebook on the Library of Congress Website (LC).

20 Ed Folsom. "Lucifer and Ethiopia: Whitman, Race, and Poetics before the Civil War and After," in A Historical Guide to Walt Whitman, ed. David S. Reynolds (New York: Oxford University Press, 2000), 50.

21 See Erkkila, 50-51, where she argues that, "by balancing and reconciling the many within the one of the poet, Whitman seeks to reconcile masters and slaves within the larger figure of the E PLURIBUS UNUM that is the revolutionary seal of the American republic. And yet even in these trial lines, Whitman's unifying act appears to be short-circuited by the irreconcilability of an economy of masters and slaves within the figure of the republican self." See also Klammer, 50-51.

22 Henry David Thoreau, Walden, ed. J. Lyndon Shanley (Princeton: Princeton University Press, 1971), 7.

23 Samuel Longfellow, ed., Life of Henry Wadsworth Longfellow: With Extracts from His fournals and Correspondences (Boston: Ticknor and Company, 1886), 2:20-21.

24 Emphasis added; Thomas, 13; Whitman, Complete Poetry and Collected Prose, ed. Justin Kaplan (New York: Library of America, 1982), 89. Hereafter CPCP.

25 Ralph Waldo Emerson, The Collected Works of Ralph Waldo Emerson, ed. Alfred R. Ferguson (Cambridge: Harvard University Press, 1971), 1:7.

26 For a discussion of b'hoy culture, see Reynolds, 103-104.

27 See M. Jimmie Killingsworth's reading of "I Sing the Body Electric" in Whitman's Poetry of the Body: Sexuality, Politics, and the Text (Chapel Hill: University of North Carolina Press, 1989), 2-15. Killingsworth argues that in the 1855 edition of Leaves of Grass, "democracy begins with the body, which is the link with nature and the common denominator among all classes, races, divided groups" (8).

28 The fact that Whitman tells us that the woman in Section 11 "owns the fine house by the rise of the bank" (CPCP, 197) underscores the futility of ownership. Though the woman is propertied, her house is clearly not part of her "Me myself" (CPCP, 191).

29 Eric Foner, The Story of American Freedom (New York: W. W. Norton, 1998), 29.

30 Eric Foner, "Workers and Slavery," in Working for Democracy: American Workers from the Revolution to the Present, ed. Paul Buhle and Alan Dawley (Urbana: University of Illinois Press, 1985), 24.

31 Bruce Laurie, Artisans into Workers: Labor in Nineteenth-Century America (New York: Noonday Press, 1989), 87.

32 Orestes Brownson, “The Laboring Classes," Boston Quarterly Review 3 (July 1840), 368. 

American Working Class, 1788-1850 (New York: Oxford University Press, 1984), 332.

34 David Roediger, The Wages of Whiteness: Race and the Making of the American Working Class (New York: Verso, 1999), 49.

35 Though Grier dates "Autobiographical Data" as a later notebook, based on the similarity of certain passages to some of Whitman's unpublished prose from 1856, he also notes that "some of the contents baffle any theory of Whitman's development" (NUPM, 209). However, a number of factors do indicate that this is the earliest of the major pre-Leaves of Grass notebooks. These factors include the fact that the autobiographical information stops in 1848 (211); the uses of phrases like "black Caesar" and "Mordecai the Jew," which are more likely to be found in Whitman's 1840s newspaper works; and, finally, the immature style of the poetry itself. For more discussion of the dating of "Autobiographical Data," in which I argue that the notebook was used as a journal over a period of several years, beginning in the late 1840s, see Higgins, 134146.

36 Ed Folsom, responding to an earlier version of this essay, noted the possibility that the passage containing this fireman, whose race is not mentioned in the 1855 text, might be another example of Whitman giving voice to a black man, as he does in the Lucifer section of "The Sleepers" (see Folsom, 46-50). Folsom's suggestion that the fireman is black is based on the notebook version and the fact that in the 1855 version the fireman notices the white faces, which, presumably, a white person would take for granted. This is an intriguing possibility, and it is certainly another example of the fluidity of identity in Whitman's poetry, though I read the mashed fireman as white based on the fact that in the 1855 text Whitman makes no reference that would lead the reader to read that figure as black; whether or not Whitman secretly saw the fireman as black, he had to know his readers would assume he was white. In regard to the white faces the fireman sees, Whitman often uses whiteness (and not blackness) as an image of beauty. Two good examples are the beautiful white swimmer of "The Sleepers" ("I see his white body ... . I see his undaunted eyes" [CPCP, 111]), and, more relevant to this case, a few pages after the mashed fireman section, Whitman's description of the firemen as equals to the old gods, and as white:

Those ahold of fire-engines and hook-and-ladder ropes more to me than the gods of the antique wars,

Minding their voices peal through the crash of destruction,

Their brawny limbs passing safe over charred laths . . . their white foreheads whole

and unhurt out of the flames (CPCP, 74; emphasis added).

Finally, the mashed fireman notes the whiteness of the faces because it contrasts with the darkness of the night; the poet wants the reader to see the image of blobs of light - the bright white faces and the torches-afloat in the dark night.

37 For a thorough discussion of "I Sing the Body Electric" and Whitman's use of the body as the ultimate locus on identity, see Killingsworth, 2-12.

38 Martin Klammer has noted about this poem and the exhortation "Examine these limbs, red black or white" that "the clustering of the three colors, unseparated by comma or other marker, serves as a visual representation of what the poet hopes the United States can become: a complete, equal, and undifferentiated amalgamation of races" (144-145). It is worth noting the implications of this vision. Whitman is actually advocating the absorption of African Americans into the American "race." He is not envisioning America as a racial multiculture. This same process occurs, though in 
a very understated form, in Whitman's unpublished free soil tract, "The Eighteenth Presidency!," in which Whitman fiercely argues against slavery without ever mentioning "blacks" or "negroes" (though "whites" are mentioned three times). Yet the essay uses the term "race" repeatedly to refer to laborers, the "new race of young men" who will confront politicians and slave owners $(C P C P, 1312)$. Further, Whitman reminds his readers that "a few generations ago, the general run of farmers and work-people like us were slaves, serfs, deprived of their liberty by law" (1315, emphasis added). I see this language as another attempt by Whitman to circumvent the static notion of race and to suggest that the problem of racial conflict would be resolved in a just and truly democratic America. How that would happen, though, Whitman neglects to say.

39 Eric Foner, Politics and Ideology in the Age of the Civil War (New York: Oxford University Press, 1980), 78-79.

40 Whitman's fullest statement about this threat is "The Eighteenth Presidency!," in which he argues that lawyers, other professionals, and slave owners have stolen America from working men and women. What is fascinating about the essay is that, as mentioned above, not once in it does Whitman use the word "black" or "negro," while "white" is used three times. The first two times occur in a passage when Whitman declares of the Southern states:

In fifteen of The States the three hundred and fifty thousand masters keep down the true people, the millions of white citizens, mechanics, farmers, boatmen, manufacturers, and the like, excluding them from politics and from office, and punishing by the lash, by tar and feathers, binding fast to rafts on the rivers or trees in the woods, and sometimes by death, all attempts to discuss the evils of slavery in its relations to the whites. (CPCP, 1311)

In the third example, Whitman asks his readers, "shall no one among you dare to open his mouth to say he is opposed to slavery, as a man should be, on account of the whites, and wants it abolished for their sake?" (1321). Whitman's point in these passages is to emphasize the cost slavery has for white workers, particularly Southern white workers. The fact that the essay contains no mention of blacks, however, is neither evidence for nor against any lack of concern for blacks by Whitman. In fact, given that many Northern whites supported slavery because they greatly feared an influx of free blacks (and that many free-soil speakers and writers were quick to make racist comments about blacks), Whitman's refusal to mention blacks in the essay can be seen as an attempt to de-emphasize this fear. And it must be remembered that, though unpublished, this is a political tract-a consciously rhetorical political document. Whitman was no stranger to politics, and his silence on this issue sounds more like the silence of a politician who knows his views on this particular issue will not be well received by his listeners, and yet who refuses to misrepresent himself.

41 Like the image of Whitman in the 1855 edition, this black teamster is shown in open-necked workman's garb looking in a "commanding" way:

His blue shirt exposes his ample neck and breast and loosens over his hipband, His glance is calm and commanding .... he tosses the slouch of his hat away from his forehead .... (CPCP, 37) 